\title{
The Issues and Tendencies of Arts Education Modernization in the Republic of Kazakhstan
}

\author{
Larissa Zolotareva ${ }^{1}$, Zhumabek Rezin $^{1}$, Zhassulan Karipbayev $^{1}$, Aimangul Burtibayeva ${ }^{1} \&$ Seifolla Bodikov $^{1}$ \\ ${ }^{1}$ Department of Fine Arts and Design, The Karaganda state University named after E. A. Buketov, Karaganda, \\ Kazakhstan \\ Correspondence: Zolotareva Larissa Romanovna, house 15, flat 113, Komissarova st., Karaganda, 100017 , \\ Kazakhstan. Tel: 8-7212-478-748. E-mail: zolotareva-larisa@yandex.ru
}

\author{
Received: March 19, 2015 Accepted: April 21, 2015 Online Published: May 14, 2015 \\ doi:10.5539/res.v7n7p385 URL: http://dx.doi.org/10.5539/res.v7n7p385
}

\begin{abstract}
The paper is concerned with development strategy of the national educational system in the Republic of Kazakhstan, principal development trends of arts education in the Republic of Kazakhstan in terms of apprehension of the national tradition based on UNESCO recommendations stated in "Road Map for Arts Education", adopting the idea of ethnocultural education; the basic content of the "Art education in the Republic of Kazakhstan: apprehension of national traditions and rapprochement of cultures" scientific and analytical report is analyzed; national policy in the area of art education in Kazakhstan, cultural heritage preservation and development are considered; training of Bachelors of Fine Arts in the area of education is represented; modern benchmarks in "Art History of Kazakhstan", formation of multicultural personality are shown; modernization problems of arts education in Kazakhstan and its study prospects are stated: promotion of creative potential, increase in education and culture status in the 21 th century is a complicated and critical task that forecasts the following prospects: interrelation of arts education and current social problems of society; increase in public information awareness and explanation of value and social significance of arts and artistic and pedagogic education; creation of demand for arts education and qualified arts teachers in the modern educational system; universalization of arts teachers' professional training; intensification and expansion of researches in the area of arts education and sharing creative knowledge at the international level; financing fiscal studies in this area. Conclusions: so far considerable experience has been gained in the area of arts education with regard to ethnocultural tradition, that allows the Kazakh system of arts education to gradually carry out the process of entering world educational space.
\end{abstract}

Keywords: the Republic of Kazakhstan, arts education, cultural heritage preservation and development, ethnocultural education and cultivation, modernization

\section{Introduction}

\subsection{Strategy of the National Educational System Development in the Republic of Kazakhstan}

Discussion on arts education condition in the Republic of Kazakhstan requires indicating principal changes in the social and economic field of the Republic of Kazakhstan that took place at the end of the $20^{\text {th }}$ - beginning of the 21 th centuries and caused reformation of the national system of education. The main objective of Kazakh education reformation is explicitly stated in the address of the head of the Republic of Kazakhstan Nazarbaev to the people of Kazakhstan "The strategy of Kazakhstan for entering 50 most competitive countries worldwide" - renewal of education quality and competitive growth of national educational system (Nazarbaev, 2006). "New economic policy "Nurly Zhol" is our major step towards entering 30 most developed countries worldwide... Our programs for advancement of education will be followed, the head of the state specified in the new Address to the People of Kazakhstan "Nurly Zhol - Way to the Future" (Address of Nazarbaev. the head of the State, 2014).

At the present stage of development strategic plans, education development programs in the Republic of Kazakhstan are based on the data of UNESCO institute. Trends of arts education in Kazakhstan are shaped by main provisions, conclusions and recommendations of the First and Second World Conferences on Arts Education supported by UNESCO (Lisbon, 2006; Seoul, 2010). 
The role and significance of arts training were specified in Road Map for Arts Education developed through discussions in the course and after the World Conference on Arts Education, March 6-9, 2006 in Lisbon (Portugal), it focuses on admitting importance of arts education in terms of creativity development, enlightenment and cultural diversity in the world (Road Map for Arts Education, 2006).

The materials of the Road Map consider national and social significance of arts education: to admit the contemporary society's need for development of educational and cultural strategies and policies, which preserve and develop cultural and aesthetic values; to take note of increasing need for creative potential in societies of different cultures as one of the most important problems of the 21th century-in this context arts education can be effective; to provide active involvement and availability of art as a major component of education for all children; to create cultural societies, centers and art museums for creative activity of the youth.

Arts education objectives are defined: promoting person's rights of education and participation in cultural life; individual abilities development; increase in education quality; promoting cultural diversity.

Three ways of arts education should be pointed out:

- The learner gains knowledge in the course of acquainting a piece of art or a performance and by means of interaction with a creative specialist or his or her teacher;

- The learner gains knowledge in the course of his/her own creative work;

- The learner gains knowledge in the course of researches and studying artistic forms and arts relation to history (history of arts).

Provisions we united as "specialists training in the area of arts education" is of scientific and pedagogical importance:

- To provide necessary support and assistance for the purpose of teaching and learning through art;

- To make professional education available for artists and teachers in order to improve arts education quality; to establish arts education departments in universities; place $a$ new priority on arts teachers education in the system of education, providing them with the opportunity to contribute to the process of studying and cultural development in a more effective way.

The task of the Seoul conference is value recognition and promotion of high-quality arts education for everybody, extension of creative opportunities in the 21th century for the youth and generation in general. The meeting of arts education subjects in Seoul was focused on identification of sociocultural aspects of education in the area of arts and development of research and practical activities by means of new conceptual and methodological instruments (International conference in the sphere of arts, 2010).

\section{Methodology and Methods}

2.1 Basic Content of the "Arts Education in the Republic of Kazakhstan: Apprehension of National Traditions and Rapprochement of Cultures" Scientific and Analytical Report

The scientific and analytical report named "Arts education in the Republic of Kazakhstan: apprehension of national traditions and rapprochement of cultures" was made by the Seoul conference (2010). The authors of this paper (Zolotareva, Rezin) were members of the expert group, which elaborated stated report. They presented its interpreted content for scientific discourse.

Basic content of the scientific and analytical report:

- National policy in the area of arts education in the Republic of Kazakhstan. Principles of national policy in arts education;

- Advanced training and continuing education of workers in arts education;

- Training of polylingual teachers;

- Cultural heritage preservation and development;

- Ethnocultural education and training;

- The scientific and analytical report represents arts education in terms of various kinds of art;

- Issue of arts education modernization in Kazakhstan.

Studies are based on collection of information concerning pressing issues and approaches in the field of arts education based on methods and recommendations of UNESCO. Methods contribute to the development of principles recorded in "Road Map for Arts Education". 
Arts education promotes such kind of education, which unite intellectual and creative abilities and makes interrelation between education, culture and art more dynamic and productive; it's designed to balance cognitive and emotional factors of personality development and thus promote formation of the Culture of the World.

The peculiarity of Kazakhstan is its ethnocultural diversity based on historical polyethnic and multifaith population make-up. Under these conditions it's important to provide opportunities for ethnic cultures restoration and development, their interaction in the interests of national unity. The adoption of ethnocultural education idea means creation of national system of education and training based on the concept of cultural and linguistic pluralism combining state-of-the-art technologies and traditional cultural values.

School as any other social group is in the constant state of changes. Since society becomes increasingly diversified and more exposed to internal conflicts, it's necessary to put an emphasis on the role of school in promoting diversity.

The ultimate goal is formation of the highly educated creative person of the 21th century familiar with various areas of knowledge and culture, socially responsible and deeply spiritual. Historically established traditions of arts education is essential factor of formation of the rising generation's national identity, intercultural interaction and responsibility for future well-being of their country.

\subsection{National Policy in the Area of Arts Education in the Republic of Kazakhstan}

Over the past decade the system of education in Kazakhstan underwent dramatic changes affecting all levels and drastically transforming approaches and interpretation of arts education.

Within a framework of State education development program implementation (currently the draft for the next stage of its implementation for 2011-2020 is developed) all levels of educations are institutionally provided by the network of corresponding organizations. The structure of education is brought into conformity with international standard classification of UNESCO (ISCOE, 1997), conditions for 12-years school are created, vocational and professional education is restructured, three-level training of specialists is introduced: bachelor-master-Ph.D.

In order to solve new issues a number of regulations and policy documents such as "Development Concept of Education of the Republic of Kazakhstan to 2015", "Comprehensive Program of Training in the Educational Organizations of the Republic of Kazakhstan for 2006-2011", "Concept of the strategic national project "Cultural heritage" for 2009-2011", "Concept of etnocultural education in the Republic of Kazakhstan", the "Deti Kazakhstana" program, the "Atameken" educational research and methodic program.

The main principles of arts education and training system modernization in the Republic of Kazakhstan are development and strengthening of national basis of education and school; recognition and assurance of native language and cultivation as absolute priority for the person; democratization of education; variability and mobility of education both by the type of property and variety of outlets for ethnocultural interests realization; availability and differentiation of educational services; openness and adaptability of the national system of education to the progressive in the world practice of arts sphere; continuity of educational activities focused on meeting person's and society's etnocultural needs; availability of regional programs of ethnocultural education with regard to ethnic and confessional differences.

Legislative ground of arts education. Adoption of the Republic of Kazakhstan law "On education" (adopted as of July 27, 2007, amended and revised as of July 4, 2013) (Republic of Kazakhstan law "On education”, 2007), "Strategic Development Plan of the Republic of Kazakhstan to 2020 " set out the priorities of educational activities and identified the main spheres of national educational system (Strategic plan, 2010).

National policy in the area of culture, defined by the law "On culture" (adopted as of December 15, 2006, amended and revised as of September 29, 2014), determines development of training system, promoting introduction to values of national and world culture, esthetic and patriotic upbringing of children and learning youth, as one of its principles (Republic of Kazakhstan law "On culture", 2006, Art. 3). The law of "State Youth Policy in the Republic of Kazakhstan" (adopted as of July 7, 2004) also secures constitutional guarantees of spiritual cultural educational professional establishing of the youth and its potential in the interests of society (Art. 3). For the purpose of society's intellectual and creative potential preservation and development, providing continuity of scientific, cultural traditions, the state maintains system of measures to support talented and gifted representatives of the youth and create conditions for their fruitful activities ("State Youth Policy in the Republic of Kazakhstan" law, 2004, Art. 11).

The role of culture in the course of the state's federal status based on multinationality and variety of confessions is emphasized. Currently, we witness the process of establishing Kazakh culture as a core, around which cultural 
community of all Kazakh nation unites, but is not dissolved. The main cause of political sphere's careful attention to culture is that culture presents a principal mechanism of interethnic relations harmonization. One of main principles of the cultural policy of Kazakhstan is in-depth study of national tradition, features of society identity, elaboration of value system of entire complex of phenomena, which can be united in the notion of "cultural national heritage", and also research of their evolution tendencies in terms of contemporaries' perception and interpretation and selection of cultural modernization forms. In this regard it's necessary to cooperate in the framework of TURKSOY for the purposes of promoting traditional art forms development, particularly through educational process.

TURKSOY is an international organization of Turkic culture, the largest in the Turkic world, which sets the task "to carry our work to systematize heritage of Turkic-speaking nations all over the world" (TURKSOY, 2009).

\subsection{Cultural Heritage Preservation and Development}

At the initiative of the president of the Republic of Kazakhstan Nazarbaev N. A. the state program "Cultural Heritage" was developed, which became the fundamental document in the area of spiritual and educational activities development, a strategic national project that defined state approach to culture. Kazakhstan is the first country of CIS, which has launched such a large-scale.

The goals of "Cultural Heritage" are study, restoration and preservation of historical-cultural heritage of the country, revival of historical-cultural traditions, promotion of the cultural heritage of Kazakhstan abroad; development of spiritual and educational sphere, protection and effective use of the country's cultural heritage.

"Cultural Heritage" became unprecedented humanitarian action in the history of Kazakhstan and demonstrated wealth of the national spiritual storehouse of the Kazakh nation to the world (Decree of the Government of the Republic of Kazakhstan, 2008).

\subsection{Training of Bachelors of Fine Arts in the Area of Education}

The system of arts education in the Republic of Kazakhstan corresponds to main spheres of national educational system and includes the following stages: nursery education; elementary education; general secondary education and additional education; vocational education; higher education; postgraduate study.

Professional training of Bachelors of Fine Arts, who will have to teach and educate the rising generation using art means under conditions of modern general education school and provide sociocultural changes in the country, becomes increasingly relevant. In this regard it seems important to represent experience concerning training of specialists of artistic and pedagogical profile in the Karaganda State University named after Buketov E. A. at professional artistic department. The "Culturological basics of poly-arts education of Bachelors of Fine Arts" fundamental research is being carried out (Zolotareva, 2012). The study is linked to the idea of interrelation of culture and education, polyart education in the context of culture. This problematics is one of top-priority ones in pedagogic science, pedagogic cultural studies and pedagogic arts history of Kazakhstan and in both non-CIS and non-CIS countries.

The optional component of "Pedagogical Art History" is included in curricula of professional artistic department at the specialization "Fine Arts and Drawing" that is caused by the priority of artistic pedagogy issue. The expedience of the special course is caused by the shift of Kazakh schools to 12-year model of education by 2020 . Currently programs regarding artistic culture of Kazakhstan (9-10 grades), world artistic culture (11-12 grades) are developed for 12-year educational system. Graduates of professional artistic, arts and graphics departments should be educated to teach polyart courses (Zolotareva, 2011).

Predicted switch to 12-year model of school education requires enhancement of material and technical base, training of art pedagogic staff of new system, availability of modern study materials, introduction of new interactive technologies in higher institutions and schools, particularly on the subject "Artistic culture of Kazakhstan" (“Art History of Kazakhstan").

In this regard curricula and syllabi on cultural studies, world artistic culture, art history in higher education institutions of the Republic of Kazakhstan are developed on the ethnocultural principle - "humanities knowledge should be linked to national culture". Besides the required course "Cultural studies", the course of "History of Kazakh Culture" is lectured at humanities departments (philosophy and cultural studies), "Art History of Kazakhstan" (or "Artistic culture of Kazakhstan") at arts departments.

Therefore, development (by the author) of one of the first teaching aids in Kazakhstan "Art History of Kazakhstan", course of lectures, electronic textbook, multimedia presentation, successful experience in teaching the same-name course become an educational research basis for this paper (Zolotareva, 2000). 


\subsection{Modern Benchmarks in Studying "Art History of Kazakhstan": Training of Multicultural Personality}

Containing extensive material on the artistic culture of Kazakhstan from the antiquity to date, the curriculum focuses on the analysis of fine arts of the 20th - the beginning of the 21th centuries, interrelation of traditions and innovations, artifacts of modern art consciousness; art culturological material is stated in the context of various arts synthesis - one of "eternal ideas" of creativity.

Teaching "Art History of Kazakhstan" is mainly designed for student's etnocultural personally formation focused on artistic culture of Kazakhstan, which is interrelated with other cultures; on the development of future specialists' artistic and humanitarian consciousness meeting the objective of ethnocultural education.

The fundamental function of ethnocultural education is training of multicultural personality: arrangement of conditions for person's identification with his or her native culture and adoption of other cultures; emphasis on the dialogue of cultures, their cross-fertilization. Multicultural personality's valuable qualities are holistic world-view, which allows reflecting complex, interrelated and interdependent nature of relations in the world, society and culture; developed linguistic consciousness promoting focus on volume world outlook; prominent historical understanding of the world, defining national mindset, "feeling of native land", ethnos; moral religious, mythologized attitude towards the world; bright artistic and aesthetic world perception.

The "Conception of ethnocultural education" emphasizes: "History of culture should hold a peculiar place". This subject largely conforms to the problems of multicultural person formation. And if it's lectured through arts history, history of world and national philosophy, history of customs and traditions, etc. it leads to training of the all-around spiritually developed personality who knows and values national and world culture (Conception, 1996).

When studying arts history of Kazakhstan it appears relevant to distinguish the following topics of the course.

The culturological topic of "The artistic culture of Kazakhstan in the context of eurasianism" is of methodological nature. The idea of eurasianism was suggested in the $20 \mathrm{~s}$ of the 20th century. It is still powerful in modern sociocultural situation, revealing its deep sense and lasting meaning in the dialogue with time. The culture of Kazakhstan, included in universal flow of culture-historical development of the human as an integral part of the world civilization, is currently considered a specific phenomenon of Eurasian attitude towards the world. Eurasian attitude towards the world includes the dialogue of cultures, their mutual influence and synthesis as well as consensus.

"Eurasianism at its core is a specific type of attitude towards the world, imbued with moral basis, able due to its practically humanistic potential to become also an integrated one, i.e. to overcome extremes of the East and the West and synthesize its best features - on the one hand, thrust of material and practical activity and psychospiritual culture, on the other hand". According to Trubetskoy N. S., "eurasianism should become the theory of the all-arounder based on discoveries of all sciences, both natural and humanities, i.e. personology that unites all knowledge in a system" (Nysanbaev,1998).

Formed in peculiar natural and landscape conditions - inland area of Eurasian steppe, middle territory of Eurasia that joined the East and the West from the earliest times, cultural traditions of tribes and nations of the steppe region absorbed various effects of cultures of surrounding nations and states, subsequently breeding its complex, distinctive and integral culture.

Art, modeling certain type of culture, vividly reconstructs integral world view of the epoch. Therefore, when studying art history of Kazakhstan, attracting to artistic and cultural traditions is of prime importance.

The subject for understanding is Scythian-Saka and Turkic tradition. The component of Scythian-Saka culture is "animal style", which reflected the nomads world view: perception of the world, world outlook, ethical and aesthetic ideals of the nomadic warrior, gods embodying space powers and acts of nature, mediate relations with environment, perception of reality as an endless battle between the Good and the Bad. Embodiment of strong animals with the use of various materials is typical for animal style: deer, feline predators, birds and others - commonly in motion, fighting. The image brings not only sacral sense but also has decorative value. To date semantics of animal style has been a matter of argument.

Modern theory of culture regarding the period of the Middle Ages in the East, Eurasian steppe widely uses data of turcokology - independent discipline of oriental studies that integrally studies languages, literary, history, and culture of nations speaking in Turkic. The cultural focuses of turcokology: mythology and history of Turkomen origin; Turkic runic written system; material culture monuments; origin, canon of the image, typology and semantics of Old Turkic sculptures (balbals), kulpytasy, regional differences. 
The works of Gumilev L. N., especially his book "Ancient Turkmen” are of great importance in studying ancient Turkomen's culture (Gumilev, 1993).

The core of original culture is world view. The historical nature of Weltanschauung is expressed in its main forms - mythology, religion, philosophy. In this regard let's examine cosmogonical and mythological ideas of nomads. Nomadic culture is a unifying factor for modern nations of Central Asia. The characteristic features of nomadic worldview are syncretism, unity with nature, perceptual unity of the world. The earliest archaic layer of the world view consists of ancient cults, myths and religions of nomads. One of the most discernable animistic cults that has come down to us is ancestor worship (aruakhs). Shamanism was and continues to be a wide spread belief among nations of Kazakhstan and Central Asia. Nomads cognized the world at the level of mythopoetic thinking, which main feature is emotional pain of the world. The content of nomadic thinking includes such essential features as imagery, mythologicality, poeticality, syncretical nature; archaic thinking was focused on harmonic coexistence of the human and nature, understanding of the world as a whole.

The issue of Kazakhstan cultural heritage preservation becomes pressing. Particularly, preservation of the Great Silk Road space holds a prominent place in the international program of UNESCO "The Great Silk Road - a route of dialogue, mutual understanding and rapprochement of cultures". Kazakh branch of the Silk Road is traced: cities and archaeological cultures.

If we touch upon the background, it's known that one of the ancient types of nomads' mobile dwellings is yurt. Embodying aesthetic ideal of the nomad, the yurt not only accumulated achievements in the area of engineering and decorative art adapted to mobile lifestyle but also became an origin of many structural and artistic solutions of cultic and secular architecture of Kazakhstan and Central Asia. The pearls of Medieval architecture of Kazakhstan are unique monuments of the 9th-12th centuries: Aisha-Bibi and Babadzha-Khatun shrines. The most striking instance is majestic architectural complex Khoja Akhmet Yassawi in Turkestan, it impresses with synthesis of cultures, epigraphic decoration, and colour symbolism. Semantically it's important to decode meaning of architectural epigraphies, stylization of canonical writings of kufi, suls, naskh, and sanctity of colour symbolism as well.

When discussing aesthetics of Kazakh way of life, the yurt as a national image of the world, we should pay attention to the structure and semantics of the yurt. The nomad neither destroys nor builds his world, but echoing Nature lives plainly. The soft round shaped yurt smoothly fits in steppe landscape, supporting natural unity of the man and nature. The form of nomads' hemispheric dwelling reflects cosmic world order, symbolism of their cosmogonical ideas. The round shaped yurt rising over surface is "the world mountain", universe foundation.

Folk arts and crafts are closely related to every-day life, primarily with yurt appearance. Folk arts and crafts embody the nomads' ideal, his artistic and cosmogonical perception of the world. The unifying basis of applied creativity is an ornament. Ornamental and decorative art history, typology, particular characteristics are studied.

Spiritual values of the Kazakhs' national traditions and customs, their reflection in fine arts are interpreted. Historical traditions, national customs reviving at the moment encapsulate material and spiritual life of the Kazakhs of the $15^{\text {th }}-18$ th centuries.

Wedding ritual is distinguished by great splendor. National games are included in the program of wedding. Games as a component of national culture became the plot base for fine arts works. Eugene Sidorkin created a large series of autolithographies named "Kazakh national games". Kanafiya Telzhanov states that centuries-long history and nation's characteristics can be "read" in the games ("Kokpar"). Suleimenov reveals deep poetic implication of the "Kyz kuu" game in his poem "Catch me"; the image created by Telzhanov is not less lyrical. The artist tries to solve perennial questions of sweets of life, youth and love based on specific material from people's life.

Kazakh epos "Alpamys Batyr" and "Koblandy Batyr" was reflected in fine arts—in the creative works of the talented Kazakh graphic artist Sidorkin.

In the context of historical-cultural tradition the modern fine art of Kazakhstan of the 20th century is conceived; main stages of professional fine arts development are considered: 20-40s; 50-60s; 70-80s; 90-00s.

Traditional archetypes in the modern fine arts of Kazakhstan. Each nation comes back to its archetypes when it has the opportunity of free development. A cultural original belongs to the archetypes of certain culture; as for Kazakh culture, these are nomadic culture of Turkic peoples and tribes, which embraced Eurasian cultural space in the Middle Ages. These archetypes are diversified: Korkyt, Shaman, Khan Tengry, Umay, Yer-Su, etc.

The study of petroglyphical heritage of Kazakhstan allows scientists to draw a conclusion on the appearance of shaman in the consciousness of nomadic communities. Over many hundred of years and to date this archetype 
has presented important mental structure and symbol of cultural world of Kazakhstan's folks.

The shaman's image in the consciousness of Kazakh nations is mythological. It is traced in all areas of arts: music, fine arts, literature. It's not a strange to modern fine arts as well. There is something that unites creativity of modern artists - this is a process of artistic self-identification, which currently becomes more active and conscious. Nowadays artists address shaman's image as personification of the spirit of the past.

Layers of ancient cultures, ethnic archetypes are embodied in modern fine arts of Kazakhstan. The worldview of Eurasian steppe is being transformed in monumental tapestries, kingly syrmaks, picturesque canvases and graphic sheets. The need for studying the past has become urgent: Kazakh artists come to it from the depths of depths eternity - among them there are Aituarov, Akanaev, Amanbaev, Begalin, Kalkabaev , Menlibaeva, Sadyhanov, etc.

Annually youth creativity festivals and competitions take place in the Republic of Kazakhstan, the most prestigious ones are "Shabyt" and "Zhiger". "Shabyt" and "Zhiger" of the last years had no limitations regarding author's approaches for creative tasks solution, as a result a wide range of artistic interpretations is revealed. Recognizing themselves successors of age-long cultural traditions of their nation, based on the experience of previous generations, young artists create their own world dissimilar to traditional and natural one. Tendencies of imaginative sign, mythological reflection prevail at exhibitions. The general thing for creative youth is address to the archetypes of antiquity. They derive their inspiration from ancient traditional culture. It allows better understanding the essence of life phenomena, spiritual aspiration of the younger generation that carries forefathers' wisdom and aesthetics of their nation.

Artistic and cultural life of central Kazaksta-Saryarka as largest multinational region is an integral part of the cultural development of the Republic.

The study of previously ideologically black-out poorly studied cultural artistic heritage of Kazakhstan of the 30-60s of the 20th century, destiny and creative activity of artists of Karlag (Karaganda Corrective Labor Camp) from the new perspectives is unfading. Culturological issues, main provisions and terminology are discussed: culture, marginal culture, their relation in the region of Karlag and Karaganda; marginal personality; memorial subcultural heritage of the camp area of Karlag and Karaganda in the context of culture theory; methodological tendencies of cultural marginal phenomena learning (ideas of Kazakh culture experts and aestheticians Karakuzova, Khasanova, Nurlanova; Gumilev's concept of "passionarity". Historical factors of marginal subculture appearance in Karaganda, specific aspects of cultural activities of artists from Karlag inmates to deportees (Humburger, Grabbe, Fonvizin, Vogeler, Eifert, etc.) are analyzed, dramatic nature of Karlag is exposed - one of the art trends of Karaganda at the end of the 20th - the beginning of the 21th centuries (Gavrilova, 2003).

The topic of "Contemporary art of Kazakhstan" is of priority. The problem of postmodern discourse in artistic culture of Kazakhstan at the turn of the century is studied. It is important to trace the influence of postmodern sets on the development of Central Asian art, the process of renewal of the Kazakh art: new understanding of ideological complex of nomadic culture in art; modification of the contemporary art of Central Asia, Kazakhstan; archetypal foundation of modern art; contemporary artists' address to the "cultural memory"; transformation of common cultural "texts" in modern projects. New conceptual and plastic ideas in theory and art practice, the specifics of creativity of modern Kazakh artists and artists of Central Asia are examined - demonstration of open cultural ties, focus on interpretative context; basic cultural codes-modern and generic, archetypical; mysteriality; game situation.

In the current cultural situation in Kazakhstan there are many styles and trends that give rise to a complex and multidimensional pluralistic artistic process. It is known that any pluralism-be it social, religious, or cultural — and it's always both a conflict and a discord, and an open dialogue. However the main trend of contemporary art is absence of bans, the possibility of full creative self-expression, drive to a radical renovation of artistic practice - the search for new imaginative system, unique and unusual.

The essence of the artistic and aesthetic program is life building through art and culture, the search for spirituality.

There are both background for polemics and creative stimulus in current contemporary culture. Postmodernism of modern era reveals contrasts for the purpose of cultural and historical perspective: "destroying old myths, but not culture, we are embedded in the history of the world" (Madanov, 1998).

We have considered the problem of arts education in the Republic of Kazakhstan in terms of apprehending national identity and rapprochement of cultures, modern benchmarks in the teaching cultural history of 
Kazakhstan and the role of this course in the formation of the multicultural, polyart personality of the teacher-bachelor of fine arts. Now it appears appropriate to systematize the topical issues of arts education modernization in Kazakhstan.

\section{Discussion}

\subsection{Problems and Prospects of Arts Education Modernization in Kazakhstan}

Actions at the national level (Government, Parliament, Ministries):

- To give priority to the development of understanding and recognition of significant contribution of arts education to the society's creative potential. To emphasize the need for modernization and adoption of the Concept of Arts Education at the state level. To include arts education in the legal framework of the Republic of Kazakhstan.

- To establish specialized state television channels "Bilim", "Education", "Culture", which, along with promotion of national cultural heritage, should translate programs on the issues of history, theory and methodology of students' creative skills and craftsmanship development.

- To explore the possibility of establishing new creative specialties for higher educational institutions "Artist-teacher" for arts and crafts and "Renovator".

- To solve the issue of opening departments for training specialists in the theory of art and culture, as well as qualifications "Theory of literary translation and literary creativity", "Culture expert with foreign language skills", "Philosopher with foreign language skills".

- To address the issue of dividing music education into classical (academic) and folklore (in a similar way as in some other countries, which encourage the development of traditional art forms).

- To promote training of specialists in the field of world culture, art culture of Kazakhstan (Bachelor of Fine Arts and World culture) at artistic graphic, professional artistic departments, i.e. to initiate the introduction of double-diploma education programs.

- To provide gold and silver medals for winners of national exhibitions-competitions of diploma works, giving them the right for grant creative internship abroad in recognized centers of art regarding given specialty.

- To support continuous training of teachers at all levels of arts education and creative workers to enhance their ability to develop students' creative, critical and innovative potential. To strengthen the relation between creative unions, workers of culture and art and artistic and pedagogical institutions. Advanced training and retraining of arts education staff is carried out by the institutes for advanced training; training courses in leading national and public universities, as well as within the framework of special placements in recognized centers of arts education in the country and abroad. Issues of teachers training and retraining system reorganization remain a priority for the national education development program. Educational curricula are focused on training of the multilingual teacher who knows innovative pedagogical technologies, skills of search, research, and creative activity, and information and distance learning technologies.

- To support the initiative of establishing the Association of Arts Education at the national level.

Actions at the level of educational institutions:

- To develop trilingual (Kazakh-Russian-English) thesaurus for Arts Education.

- To introduce a required course of course photography at artistic graphic departments, to introduce an optional study of photography in non-profession-oriented institutions and provide conditions for amateur video studios creation.

- To recommend the Union of Cinematographers and journalists of Kazakhstan to take patronage over children photo and videostudios, to promote the opportunity of creating photo and videostudios in orphanages.

- To promote the establishment and activity of UNESCO departments and observatories in Arts Education.

\section{Conclusions}

Strengthening creative potential, improving the status of education and culture in the 21 th century is a complex and important task that forecasts the following prospects:

- Relation of arts education with modern social problems;

- Increase in public information awareness and explanation of value and social significance of arts and artistic and pedagogic education; 
- Creation of demand for arts education and qualified arts teachers in the modern educational system;

- Universalization of arts teachers' professional training;

- Intensification and expansion of researches in the area of arts education and sharing creative knowledge at the international level;

- Financing fiscal studies in this area;

- Attraction of the most qualified and competent experts in arts education from different regions of the country for comprehensive studies.

Summarizing the modern analysis of educational trends in the Republic of Kazakhstan it can be concluded that so far considerable experience has been gained in the area of arts education with regard to ethnocultural tradition that allows the Kazakh system of arts education to gradually carry out the process of entering world educational space.

\section{References}

Barmankulova, B., \& Ordabaev, A. (1998). Conception of ethnocultural education in the Republic of Kazakhstan (August 7, 1996). In Catalogue of the "Vavilonskaya bashnya" art project (p. 58). Almaty: Kazakhstanskaya pravda.

Gavrilova, E. P. (2003). Memorial of the Karaganda city: Karlag, culture, artists (p. 135). Karaganda: Arko LLP. Gumulev, L. N. (1993). Ancient Turkmen (p. 512). Moscow: the "Klyshnikov-Komarov and Co." partnership.

Isimbaeva G. I. (2010). Arts education in the Republic of Kazakhstan: Apprehension of national traditions and rapprochement of cultures: Scientific and analytical report (p. 61). Almaty: Kazakh National Federation of UNESCO Clubs.

Kazakhstan Government decree as of November 6, 2008 No. 1016 "On the conception of the "Cultural heritage" strategic national project for 2009-2011”. (2008). Retrieved from http://egov.kz/wps/portal/Content? contentPath=/library2/1_kazakhstan/kr/article/cult_nasl\&lang=ru

Law "State Youth Policy in the Republic of Kazakhstan". (July 15, 2004). Kazakhstanskaya pravda, No.158.

Law of the Republic of Kazakhstan "On culture". (December 26, 2006). Kazakhstanskaya pravda, No.271.

Law of the Republic of Kazakhstan "On education". (August 15, 2007). Kazakhstanskaya pravda, No. 127.

Nazarbaev, N. A. (2006, March 2). The strategy of Kazakhstan for entering 50 most competitive countries worldwide (No. 45-46). Kazakhstanskaya Pravda.

Nysanbaev A. N. (Ed.). (1998). Eurasian integration policy of the Republic of Kazakhstan (p. 135). Almaty.

Road Map for Arts Education: Building creative potential for 21th century. (2006). World Conference on Education in the area of Arts, Lisbon. Retrieved from http://portal.unesco.org/culture/en

Strategic plan of development of the Republic of Kazakhstan to 2020. (2010). Compilation of the acts of the President of the Republic of Kazakhstan and Government of the Republic of Kazakhstan (pp. 163-220). Astana.

Tyurksoy. (2009) http://www.turkishnews.ru/kultura-turizm-otdyh-v-turcii/news/organizaciya-tyurksoybudet-pereimenovana

Zolotareva, L. R. (2000). History of Kazakh Arts: Study guide (p. 332). Karaganda: Karaganda State University named after Buketov E. A.

Zolotareva, L. R. (2011). Pedagogical art history (p. 396). Almaty: Bylym.

Zolotareva, L. R. (2012). Culturological framework of poly-arts education (p. 510). Saarbrücken, Germany: LAP LAMBERT Academic Publishing.

\section{Copyrights}

Copyright for this article is retained by the author(s), with first publication rights granted to the journal.

This is an open-access article distributed under the terms and conditions of the Creative Commons Attribution license (http://creativecommons.org/licenses/by/3.0/). 